\title{
Archaeogenetics of Late Iron Age Çemialo Sırtı, Batman: Investigating maternal genetic continuity in North Mesopotamia since the Neolithic
}

\author{
Reyhan Yaka ${ }^{1}$, Ayşegül Birand ${ }^{1 *}$, Yasemin Y1lmaz ${ }^{2 *}$, Ceren Caner ${ }^{1}$, Sinan Can Açan ${ }^{1}$, Sidar \\ Gündüzalp ${ }^{3}$, Poorya Parvizi ${ }^{1}$, Aslı Erim Özdoğan ${ }^{4}$, Zehra İnci Togan ${ }^{1 \$}$, Mehmet Somel ${ }^{1 \$}$
}

\author{
Affiliations \\ ${ }^{1}$ Department of Biological Sciences, Middle East Technical University, Ankara, Turkey \\ ${ }^{2}$ Department of Archaeology, Düzce University, Düzce, Turkey \\ ${ }^{3}$ Department of Prehistory, İstanbul University, İstanbul, Turkey \\ ${ }^{4}$ Department of Archaeology, Çanakkale Onsekiz Mart University, Çanakkale, Turkey \\ *equal contribution \\ $\$$ co-supervised the study
}

\begin{abstract}
North Mesopotamia has witnessed dramatic political and social change since the Bronze Age, but the impact of these events on its demographic history is little understood. Here we study this question by analysing the recently excavated Late Iron Age settlement of Çemialo Sirtı in Batman, southeast Turkey. Archaeological and/or radiocarbon evidence indicate that the site was inhabited during two main periods: the first half of the 2nd millennium BCE and the first millennium BCE. Çemialo Sırtı reveals nomadic items of the Early Iron Age, as well as items associated with the Late Achaemenid and subsequent Hellenistic Periods. Mitochondrial DNA (mtDNA) haplotypes from 12 Çemialo Sırtı individuals reveal high genetic diversity in this population, conspicuously higher than early Holocene west Eurasian populations, which supports the notion of increasing population admixture in west Eurasia through the Holocene. Still, in its mtDNA composition, Çemialo Sirtı shows highest affinity to Neolithic north Syria and Neolithic Anatolia among ancient populations studied, and to modern-day southwest Asian populations. Population genetic simulations do not reject continuity between Neolithic and Iron Age, nor between Iron Age and present-day populations of the region. Despite the region's complex political history and indication for increased genetic diversity over time, we find no evidence for sharp shifts in north Mesopotamian maternal genetic composition within the last 10,000 years.
\end{abstract}

\section{Keywords}

North Mesopotamia, Çemialo Sırtı, Achaemenid Period, Neolithic, ancient DNA, mitochondrial DNA, demographic history, Lower Garzan Basin

\section{Abbreviations}

CML: Çemialo Sırtı; LBK: Linearbank culture; LBKT: Linearbandkeramik culture in Transdanubia; MDS: multidimensional scaling 


\section{Introduction}

North Mesopotamia became densely populated around 12,000 BCE, after the Last Glacial Period (Rosenberg and Erim-Özdoğan, 2011). Both during the Pre-pottery Neolithic A (PPNA) and Pre-pottery Neolithic B (PPNB) the region was a favourable geographical zone for sedentary and nomadic hunter-gatherers. Besides excavated PPNA sites (e.g. Tell Aswad, Tell Qaramel, Djade El-Mughara, Mureybet, Jerf el Ahmar, Göbekli Tepe, Hallan Çemi, Hasankeyf Höyük, Çayönü, Qermez Dere, Nemrik) many regional settlements have been detected in surveys. Most of these PPNA sites were abandoned by the PPNB (except for a few exceptions, e.g. Tell Aswad, Mureybet, Tell Qaramel, and Çayönü), while many new, large and complex sedentary communities emerged during the PPNB across north Mesopotamia and the Levant, between ca.7600-6200 BCE (e.g. Tell Ramad, Tell Halula, Bouqras, Tell ain el-Kerkh, Abu Hureyra, Tell Seker al-Aheimar, Tell Fekheriye, Cafer Höyük, Nevali Çori, Mezraa Teleilat). The beginning of crop and animal domestication, earliest metallurgy, various burial practices, increasing in usage of Anatolian obsidian, special buildings with particular items and decorations were fundamental features of the PPNB period. By ca.6600-6200 cal. BCE, however, with the $8.2 \mathrm{ka}$ cold/arid event, rapid climate change-driven social and economic effects led to the decline of PPNB societies in the Levant, north Mesopotamia and Anatolia, resulting either in abandonment of settlements or their reduction in size (Staubwasser and Weiss 2006). Archaeological data indicate that the Neolitization of the Balkans and the Caucasus also occurred during this time period, between ca.6600-6000 cal. BCE (Weninger et al 2006; Weninger et al 2009; Weninger et al 2014).

The exact timing of the beginning of the Pottery Neolithic (PN) in north Mesopotamia is still debated. In addition to the early excavated PN sites in Syria and Iraq (e.g. Tell Şeker al Aheimar, Jarmo, Kül Tepe, Tell Hassuna), recently dug Sumaki Höyük in the north of Lower Garzan Basin and Salat Camii Yanı at Bismil-Diyarbakır also display changes in land choice from PPNB (Erim-Özdoğan 2011). After temperature and precipitation conditions improved, north Mesopotamia was densely reoccupied, with the Halaf culture (cal. 5400-4990 BCE), carrying both sedentary and semi-nomadic characters, flourishing in the region. The Halaf was eventually replaced by the Ubeid culture (5500-4000 BCE) of south Mesopotamian origin, followed by another south Mesopotamian originated culture, Uruk. The Uruk controlled the region until ca.3200 BCE, when the $5.2 \mathrm{ka}$ event caused their collapse through severe drought (Staubwasser and Weiss 2006). Subsequently, small settlements of local Late Chalcolithic cultures spread across the region up to the Caucasus (Marro 2010). Between 2500-1500 BCE, the Holocene $4.2 \mathrm{ky} \mathrm{cold} /$ arid event was likely the main factor in the collapse of Akkadian Empire (ca.2350-2150 BCE). Following the 4.2 ka event, the abandoned lands of north Mesopotamia and Palestine were reoccupied intensively and reorganized by sedentarized nomadic pastoralists (Staubwasser and Weiss 2006). Meanwhile, the region witnessed major political changes (Nissen and Heine 2003): Neo-Assyrian influence (10th-7th century BCE), was followed by that of Babylon (6th century BCE), the Achaemenid Empire of Persia (6th-4th century BCE), and the empires of Alexander and the Seleucid of Hellen origin (4th-2nd century BCE). Between 2 nd century BCE and 7th century CE, the region was dominated by Rome/Byzantium in the west, and Parthians and later Sasanians in the east. North Mesopotamian region underwent Muslim Arab conquests in the 8th century, and from the 11th century onward, it fell under the rules of central and east Asian-related groups, including the Seljuks, Mongols, and the Ottomans. Notably, these major political changes have also been attributed to more recent rapid climate change and demographic effects (Büntgen et al., 2016; Kuzucuoğlu, 2015)

Still, north Mesopotamia's demographic history remains little known. One major question is whether rapid climate change-driven population fluctuations, as during the end of the PPNB, involved population replacement from distant regions. Such replacement would appear as allele 
frequency shifts in the regional gene pool. Another question involves whether political and cultural change was accompanied by major gene flow events, or whether immigration was a weak force relative to social forces. The genetic legacy of migration and resettlement policies of various imperial states (including Assyrians, Seleucids, Romans, and Ottomans; see Schechla, 1993; Zürcher 2009; Nissen and Heine 2003; Woolf 2015), is likewise unclear.

Ancient DNA (aDNA) today holds great potential to address these questions, and methods have improved to the point that aDNA from temperate regions can be recovered with reasonable success. Yet, there has been only a single study of north Mesopotamia archaeogenetics published to date. This work investigated human mitochondrial DNA (mtDNA) from PPNB sites from north Syria, Tell Halula and Tell Ramad (Fernández et al., 2014). Ten individuals' haplotypes were obtained, which showed high similarity (i.e. low $F_{S T}$ ) to the mtDNA composition of modern-day populations of the Near East, Caucasus and south Europe, with the highest similarity to Cyprus. Still, the authors of this study noted clear differences in haplotype frequencies between the Neolithic north Syrian population and those of modern-day southwest Asia. They suggested that such shifts could arise due to immigration or genetic drift, although they did not address these hypotheses explicitly.

Here we present archaeological and genetic data from Çemialo Sırtı, Batman, Turkey, a culturally diverse Late Iron Age site in north Mesopotamia. Comparing Çemialo Sirtı mitochondrial DNA sequences with those of ancient and modern-day west Eurasian populations we study admixture and continuity in the demographic history of north Mesopotamia.

\section{Archaeology of Çemialo Sırtı}

Çemialo Sırtı (CML) is located in the territory of the Yazıhan Village, Gedikli hamlet of the Beşiri district in Batman Province, southeast Turkey (Fig. 1, SI Fig. 1). The site is located in the middle of the Lower Garzan Basin watered by the Garzan Stream, one of the main tributaries of the Tigris River. The site lies on a low ridge approximately 10-12 $\mathrm{m}$ above the plain at an elevation of 503-512 m on the south bank of the Garzan Stream, at the junction of Malabini and the Garzan Streams. It is within the direct impact area of the Ilisu Dam, which started to be constructed in the early 2000's. Rescue excavations were started in 2009 and continued between 2013-2015 at two sites, Gre Amer and Çemialo Sırtı. An area of $3600 \mathrm{~m}^{2}$ has been exposed at the site displaying material culture elements characteristic of two periods: the first half of the 2 nd millennium $\mathrm{BCE}$ and the 1st millennium BCE.

During the Artuqid Period (12th-14th centuries CE), the Lower Garzan Plain appears to have played an active role in the commercial route system between Mesopotamia, Iran, and Caucasus, as well as west and north Anatolia (Supplementary Information). Roman and Byzantine presence in the region is less evident, but according to surface surveys (Erim-Özdoğan and Sarialtun 2011) and results from rescue excavations at Gre Amer and Çemialo Sırt1, the Garzan Plain was densely occupied during the 1st millennium BCE. Both Gre Amer and Çemialo Sırtı display material culture evidence from diverse traditions, detected not only in architecture but also in artifacts of daily use and in burial practices.

In Çemialo Sırt1, the Late Achaemenid Period (550-330 BCE) (Sampson, 2008; Curtis and Tallis, 2005; Ahmad et al., 2013) presence is identified by Triangle Ware, as well as typical pottery forms and bronze objects like kohl sticks with castellated heads known from the Achaemenid layers of the sites Nimrud, Deve Hüyük, Kamid el-Loz, Tell Jigan, and Pasargadae (Curtis, 2004). Çemialo Sirtı also yields Hellenistic footprints, represented by a silver Tetra Drahmi of Alexander the Great (ca. 325-323 BCE), pottery sherds, a head of a terracotta figurine. Traces of temporal architectural elements, pits, and items such as dog burials and crude pottery, generally attributed to Early Iron 
Age nomadic peoples, have also been discovered (Supplementary Information).

A total of 47 graves have been excavated at Çemialo Sırtı, including pithos/jar burials $(n=19)$, stone cists $(n=10)$ and pit graves $(n=18)$ (SI Figs. 2-3). Most individuals were placed contracted on their left or right sides, with or without burial goods. Burial characteristics include the use of stone cists and pit graves common in north Mesopotamia since the Bronze Age, such as reported for Titriş Höyük and Lidar Höyük (Algaze et al., 1995; Hauptmann, 1982, 1984, 1987, 1993; Matney and Algaze, 1995), and these features seem to have continued into the Late Achaemenid Period. One exception is an individual with ornaments suggesting Early Iron Age cultures, such as stone bell-shaped hollowed amulet carried by a copper wire. Different burial practices have been recorded in different sites of the eastern and western parts of the Near East during the Hellenistic period, such as flexed inhumation in Nimrud, Iraq (Oates and Oates, 1957), and cremation, flexed, or extended inhumation in Antandros, west Turkey (Yağı, 2009); some of the graves at CML, such as SK35, a body laid on its back holding an imitation of a black glazed plate, can also be attributed to Hellenistic Period. Further information on the site and the graves are provided in the Supplementary Information and SI Figs. 1-3.

\section{Materials and Methods}

\subsection{Samples}

The samples reported in this study were recovered during excavations at Çemialo Sırtı site in 2013-2014 field season in accordance with aDNA study guidelines. We analyzed 16 individuals excavated from three different locations: conglomerates on top of the ridge, around the middle of hillside, and on the skirt of the ridge (Supplementary Table S1). All were primary burials and dated to the Late Iron Age based on archaeological context, except one individual whose ornaments implied an earlier period (see section 2). We used 22 bone and tooth samples from 16 human skeletons for DNA extractions (eight female adults, three male adults, three pre-adults, and two adults whose sex was undetermined).

Three of these skeletons were radiocarbon dated to 535-395 cal. BCE, 395-205 cal. BCE, and 390-205 cal. BCE (95\% probability) by Beta Analytic, Miami, USA (Supplementary Table S1). Thus, all three potentially overlap with the Late Achaemenid Period (550-330 BCE), and the latter two may also overlap with the subsequent Hellenistic Period (330-31 BCE).

\subsection{Contamination avoidance}

Genetic analyses were carried out at the aDNA facilities of the Middle East Technical University (METU). We used all the precautions to avoid contamination (Gilbert et al., 2005; Olivieri et al., 2010; Ottoni et al., 2011; Paabo et al., 2004): using samples cleanly stored at site without washing, using a dedicated aDNA laboratory in a building physically separated from the post-PCR laboratory and under strictly controlled conditions, following irreversible steps throughout aDNA extraction, PCR and post-PCR laboratory procedures, using negative controls at each step of the experimental processes, independent repeats of experiments at multiple times for reproducibility. Genetic profiles of team members (all archaeologist, anthropologist, and laboratory researchers involved) were also determined for comparison with genetic profiles of ancient individuals to avoid contamination from modern human DNA. Details on contamination avoidance procedures are provided in the Supplementary Information.

\subsection{Ancient DNA extraction, amplification, and authenticity assessment}


After decontamination and pulverization of tooth and/or phalanx samples, 0.2-0.3 g of powder was digested in a proteinase-K lysis buffer and DNA extracted through silica-based spin columns following Ottoni et al. (2011). The first and second hypervariable regions (HVRI-HVRII) of mtDNA were amplified and sequenced in multiple independent experiments using five and two overlapping fragments (ranging from 109-166 bp in size) to read $357 \mathrm{bp}$, between nucleotide positions (np) 16009-16365, and 217 bp, between np 49-265, respectively, for the HVI and HVII regions (Ottoni et al., 2011).

PCR amplification procedures and cycling conditions followed Ottoni et al. (2011) with slight modifications. We conducted minimum three independent extractions from each sample, and three independent amplifications from each extraction. We required clear sequences that were consistent across all the overlapping fragments from independent extract and PCR repeats. Samples from four individuals, for which these attempts produced less than 3 consistent sequences, were discarded. Sequences were confirmed by considering reads from both strands of the mtDNA and determined from overlapping HVRI and HVRII fragments. We confirmed that none of the mtDNA haplotypes of research team members matched the ancient haplotypes (Supplementary Table S8). We further recorded the frequency and types of nucleotide changes among repeated sequence reads for each individual, especially $\mathrm{C}->\mathrm{T}$ transitions, which is the hallmark of postmortem damage in authentic aDNA (Sawyer et al., 2012; Olivieri et al., 2010; Paabo et al., 2004). Details regarding sample preparation, aDNA extraction and amplification reactions, the list of primers used, purification and sequencing processes, precautions taken to minimize contamination and criteria adopted for assessing authenticity are provided in the Supplementary Information and Supplementary Table S7.

\section{4. mtDNA haplogroup determination and population genetic analysis}

mtDNA haplogroups of successfully amplified Çemialo Sırtı individuals were determined based on the SNPs at informative nucleotide positions of HVI and HVII region sequences (Supplementary Table S2) using the Cambridge Reference Sequence (CRS) (Anderson et al., 1981) as reference sequence and mtDNA Phylotree build 17 (van Oven and Kayser, 2009).

Çemialo Sirtı haplogroups and sequences were compared with published data from 15 ancient Eurasian populations (Mesolithic Eurasia, Neolithic, Bronze Age, and Iron Age west Eurasia, as well as Roman and Byzantium) and 13 modern-day populations from west Asia and southeast Europe. These datasets were chosen to contain a minimum of 10 individuals each (Supplementary Table S3).

Multiple sequence alignments were performed using ClustalW software (Thompson et al., 1994; http://www.ebi.ac.uk/Tools/msa/). Within mtDNA HVRI, a 240 bp region was shared among all populations (between np 16126-16365 on the CRS). To measure population genetic differentiation among populations we calculated Slatkin's linearized $F_{S T}$ between pairs of populations (Slatkin, 1995) using Arlequin v.3.5.2 (Excoffier and Lischer, 2010). Significance of $F_{S T}$ values was calculated using Arlequin by 10,000 random permutations of population labels. To visualize genetic differentiation between the populations, the pairwise $F_{S T}$ matrix was summarized using two-dimensional non-metric multidimensional scaling (MDS) using the "metaMDS" function in the R package "vegan" (Oksanen, 2008) and plotted in R v.3.2.4 (http://www.r-project.org/). Pairwise $F_{S T}$ with Çemialo for all populations was displayed on a geographical map using the "rworldmap", "maps" and "SDMTools" packages implemented in R.

Haplotype (gene) diversity, the probability that two randomly chosen haplotypes are different in the sample (Nei and Kumar, 2000), was estimated for all population samples using Arlequin. Absolute 
and relative frequencies of mtDNA haplogroups were further calculated using a Bayesian calculator (http://www.causascientia.org/math_stat/ProportionCI.html) presenting the estimated frequencies together with the 95\% Bayesian credible intervals (CI) in Çemialo Sırt1, Neolithic north Syria, modern-day Syria and southeastern Anatolia populations. Details about statistical analysis and populations data are given in the Supplementary Table S3 and Supplementary Information.

\subsection{Coalescent simulations of population continuity}

For specific pairs of diachronic population comparisons, a recent population $X$ and a more ancient population $Y$, we tested the null hypothesis that the observed $F_{S T}$ value could arise solely by genetic drift (i.e. population continuity). We compared the observed $F_{S T}$ values with those generated by coalescent simulations.

For each pairwise comparison $X$ and $Y$, separated by a certain number of generations, we simulated DNA sequence data using the fastsimcoal2 simulation software (Excoffier et al., 2013). We used a demographic model of exponential growth (e.g. Ottoni et al., 2016; Sverrisdóttir et al., 2014) employing a range of parameter values, i.e., different effective population sizes (Supplementary Table S5). The exponential growth rate was calculated as the natural logarithm of the ratio of the population sizes of $X$ and $Y$. We assumed a generation time of 25 years, and the mutation rate of $3.6 \times 10^{-6}$ per site per generation for the human mtDNA HVRI (Richards et al., 2000). We performed 1000 simulations for each combination of population sizes, summing up to $250,000-400,000$ simulation runs for each comparison (see section 3.5, Fig. 4A). In each simulation, we sampled from the population serially through time under the exponential population growth scenario (Sverrisdóttir et al., 2014).

We carried out 1000 simulations for each combination of population sizes, calculated $F_{S T}$ using Arlequin v.3.5.2 (Excoffier and Lischer, 2010), and calculated the proportion of simulated $F_{S T}$ values that are greater than the observed $F_{S T}$. If the observed $F_{S T}$ was found within the range of $F_{S T}$ values from the simulations, this would be compatible with population continuity between the two populations (including migration from genetically similar populations), or could indicate a lack of statistical power. Conversely, if most simulations yielded $F_{S T}$ values smaller than that observed, the null hypothesis of continuity can be rejected (assuming that the demographic scenario and parameters are valid). Such rejection could be interpreted as gene flow and/or migration from genetically distinct third populations that led to differentiation of $X$ from $Y$, or equivalently, that $X$ from $Y$ did not belong to the same ancestral population.

\section{Results}

We studied a total of 16 Çemialo Sırtı individuals' remains (Supplementary Table S1). Of these, three randomly chosen individuals were radiocarbon dated to between 535-205 cal. BCE, consistent with archaeological evidence for Late Achaemenid (550-330 BCE) (Sampson, 2008; Curtis and Tallis, 2005; Ahmad et al., 2013) presence in Çemialo Sırt1 (section 2). In the rest of this study we therefore assume that these individuals represent a Late Iron Age north Mesopotamian population.

We obtained reproducible mtDNA HVRI-HVRII (HVI and HVII regions) sequences from 12 out of 16 individuals' remains, including 9 teeth and 3 phalanx samples (75\% success rate). Authenticity was assessed by requiring at least 3 overlapping fragments from independent extract and PCR repeats, by the presence of cytosine deamination indicative of postmortem decay, and lack of match to mtDNA haplotypes of the research team (section 3.3). All ancient mitochondrial DNA sequences produced in this study have been deposited in the NCBI GenBank database (accession number 
pending).

\section{1. mtDNA haplogroup composition of Çemialo Sırtı}

We determined mtDNA haplogroups for the 12 Çemialo Surtı individuals (Table 1 and Supplementary Table S2). The most common haplogroup was $\mathrm{H}(n=5)$, one of the most abundant types in present-day Europe and in the Near East (Achilli et al., 2004; Richards et al., 2000). We also observed subtypes of haplogroup R (R2 and R6, $n=1$ each), M (M1a1, $n=1$ ), and HV (HV and HV8, $n=1$ each). One individual belonged to subtype of N1(N1a1a1a), a common haplogroup in Neolithic farmer populations (Brandt et al., 2014; Szécsényi-Nagy et al., 2015), and another belonged to a haplogroup common in European Paleolithic and Mesolithic populations, U2 (Bramanti et al., 2009; Brandt et al., 2014; Der Sarkissian et al., 2013; Krause et al., 2010). Çemialo Sirt1 haplogroup frequency credible intervals largely overlapped with those from Neolithic north Syria $(n=10)$, modern-day southeast Anatolia $(n=224)$, and modern-day Syria $(n=48)$ (Table 1$)$. An exception to this pattern was macrohaplogroup M, which was absent in both the Neolithic and modern-day Syrian datasets. We found no obvious association between haplogroup type and burial characteristics (pithos, location, or presence of burial gift) (Supplementary Table S1).

\subsection{Population comparisons of genetic diversity}

We compared the Late Iron Age Çemialo Sırtı population with mtDNA datasets representing 14 ancient and 13 modern-day populations from west Eurasia, chosen to include at least 10 individuals (Fig. 2 and Supplementary Table S3). The 14 published ancient mtDNA datasets comprised populations from Mesolithic west Eurasia (Bramanti et al., 2009; Der Sarkissian et al., 2013), Pre-Pottery Neolithic northern Syria (Tell Halula and Tell Ramad) (Fernández et al., 2014), Pottery Neolithic northwest Anatolia (Barcin) (Mathieson et al., 2015), Early Neolithic Central Europe (LBK, Starčevo, LBKT) (Brandt et al., 2014; Szécsényi-Nagy et al., 2015), Early and Late Neolithic southwest Europe (northeast Iberia and Spain Treilles culture) (Gamba et al., 2012; Lacan et al., 2011), Bronze Age Crete (Minoan) (Hughey et al., 2013), Early Bronze Age Central Europe (Unetice culture) (Brandt et al., 2014), as well as Roman and Byzantine Period southwest Anatolia (Sagalassos) (Ottoni et al., 2011, 2016). This ancient dataset contained 467 individuals in total, including Çemialo Sırtı individuals ( $n=10-88$ individuals per population, median=24). The modern-day populations were chosen from west Asia and south Europe (Alkan et al., 2014; Brisighelli et al., 2012; Comas et al., 1996; Comas et al., 2004; González et al., 2007; Irwin et al., 2008; Nasidze and Stoneking, 2001; Ottoni et al., 2011, 2016; Roostalu et al., 2007; Schönberg et al., 2011; Serin et al., 2016; Vernesi et al., 2001), summing up to a total of 1483 individuals $(n=30-286$ individuals per population, median $=90)$.

We estimated haplotype diversity within all populations based on a $240 \mathrm{bp}$ HVRI region shared among all sequences (Supplementary Table S6). Diversity estimates for ancient Eurasian populations $(0.818-0.989$, median $=0.927)$ were noticeably lower than those for modern-day Eurasians (0.959-0.995, median=0.977) (Mann-Whitney U-test $\mathrm{p}<0.001$, assuming independence among populations). Our observation that modern-day west Eurasian populations carry higher genetic diversity than ancient west Eurasians groups agrees with earlier reports based on nucleotide diversity and runs of homozygosity estimated from ancient and modern whole genomes (Jones et al., 2015; Kılınç et al., 2016; Skoglund et al., 2014). Interestingly, Late Iron Age Çemialo Sırtı had the highest haplotype diversity estimate among the 15 ancient populations, and modern-day Syria (but not Turkey or southeast Anatolia) had the highest diversity estimate among the 13 contemporary populations. The lowest haplotype diversity levels were found for Mesolithic European groups and in Neolithic north Syria. 


\subsection{Population differentiation}

We calculated pairwise $F_{S T}$, an estimate of between-population genetic differentiation relative to within-population diversity, among all 15 ancient and 13 modern populations' mtDNA sequences, and tested statistical significance by random permutations. $F_{S T}$ values between Late Iron Age Çemialo Sırtı and other populations are depicted in Fig. 2 and Fig. 3. $F_{S T}$ values between Çemialo Sirt1 and other ancient Eurasian populations (range $=0.026-0.389$, median $=0.068$ ) were generally higher than those between Çemialo Sırtı and modern populations (range $=0.009-0.056$, median $=0.033$ ), which is expected given low diversity in ancient Eurasian populations (section 4.2).

Among ancient populations, the mtDNA composition of the Çemialo Sırtı was closest to those of Neolithic north Syria and to Neolithic northwest Anatolia, followed by Roman Period Anatolia and Bronze Age Crete. Çemialo Sırtı showed higher differentiation from Early Neolithic European Neolithic populations and to Byzantine Period Anatolian, and was most differentiated from European Mesolithic populations. Among modern-day populations, Çemialo Sırtı had lowest $F_{S T}$ with Cyprus, followed by Jordan, Azerbaijan, Turkey and Syria, and higher $F_{S T}$ values with Greece, Italy, and Armenia. Çemialo Sırtı mtDNA composition thus showed higher affinity to those of geographically proximal populations of the last 10,000 years, with increasing genetic differentiation upon increasing distance from north Mesopotamia. Byzantine Period Anatolia (Sagalassos) and modern-day Armenia were the only exceptions to this pattern, being geographically close but genetically more differentiated (Fig. 2). Among the $F_{S T}$-based comparisons between Çemialo Sirtı and ancient or modern-day populations, $11 / 14$ and 6/13 were significant as measured by random permutations, respectively ( $p<0.05$, Fig. 2, Supplementary Table S4; we note that statistical significance is a function of both the level of differentiation and of sample size).

We further summarized pairwise mitochondrial $F_{S T}$ values among all 15 ancient and 13 modern-day populations using multidimensional scaling (Fig. 3A). As with similar summaries of ancient and modern nuclear genomic variation of west Eurasian populations (e.g. Lazaridis et al., 2014; Skoglund et al., 2014), the main coordinates set apart early/mid Holocene groups, while more recent populations were represented in the middle, implying increasing population admixture over time (K1lınç et al., 2016; Lazaridis et al., 2016). In the multidimensional scaling plot, the first dimension separated ancient populations of Near Eastern origin (including early Neolithic Central Europe) and Mesolithic European populations. The second dimension set apart Central Europe (LBK and Mesolithic Central Europe) from Mesolithic east Europe and Neolithic southwest Asia. The $F_{S T}$ measures summarised in the MDS plot also underscored the close affinity between the Late Iron Age Çemialo Sırtı population and that of Neolithic north Syria, both from the same region but separated by over seven millennia (Fig. 3).

\subsection{Testing population continuity with Çemialo Sırtı}

Although the above analysis hints at population continuity in the region, we found statistically significant differentiation in comparisons of Late Iron Age Çemialo Sırtı versus a number of neighboring modern-day populations: Iran, southeast Anatolia, Greece, and Armenia $\left(F_{S T}=0.036\right.$, $0.033,0.046$, and 0.056 , respectively; permutation test $p<0.05)$. If we assume that Çemialo Sırtı was part of a wide regional population comprising west Asia and southeast Europe during the Late Iron Age, then these modern-day populations must have differentiated from Çemialo Sırtı over the past $\sim 2500$ years ( $\sim 100$ generations). Three forces could account for such differentiation: natural selection, migration, and/or genetic drift. Selection on human mitochondrial DNA has been reported (Balloux et al., 2009) but strong selection in resident human populations within such short time 
frame is unlikely. By contrast, population differentiation by migration from genetically distinct populations is a plausible factor, especially given the region's history of frequent social and political change (section 1). Finally, genetic drift is a ubiquitous force in natural populations. If it can be shown that genetic drift cannot solely explain differentiation, one may presume the role of migration, or that the two diachronic samples did not belong to the same population.

To address this, we conducted population genetic simulations using the fastsimcoal 2 simulation software to test whether the observed differentiation between Çemialo Sırtı and a modern-day population can be explained purely by genetic drift within the same gene pool within a given time interval, assuming an exponential growth model, and a wide range of population sizes. We obtained no evidence to reject continuity between Çemialo Sırtı versus Syria, Iran, or southeast Anatolia (SI

Fig. 4B, C, F), such that for the majority of parameter value combinations the observed $F_{S T}$ was within the null $F_{S T}$ distribution ( $>99 \%$ of parameter value combinations with $p>0.10$, Fig. 4 ). There was only partial evidence to reject continuity with Armenia (observed $F_{S T}=0.0493,27 \%$ of parameter value combinations had $p<0.10$ ), and strong evidence to reject continuity with Greece (observed $F_{S T}=0.0437,85 \%$ of parameter value combinations had $p<0.10$, SI Fig. $4 \mathrm{G}$ ). The difference between comparisons with Armenia and with Greece appears to be due to sample size and hence statistical power differences (Supplementary Table S5).

Using the same approach we next tested continuity between Çemialo Sırtı and ancient west Eurasians. Here we could not reject continuity with Neolithic north Syria and northwest Anatolia, or with Roman Anatolia ( $>99 \%$ of parameter value combinations with $p>0.10$ ). In contrast, simulations suggested a general lack of continuity in comparisons of Çemialo Sırtı versus European Mesolithic and Early Neolithic populations, as well as Byzantine Anatolia ( $>50 \%$ of parameter value combinations with $p<0.10$ ) (Supplementary Table S5). The exceptions to this pattern were Early Neolithic Iberia (observed $F_{S T}=0.071$ ), and Early Bronze Age Central Europe (Unetice Culture, observed $F_{S T}=0.046$ ), for which continuity with Çemialo Sirtı could not be rejected (Supplementary Table S5). Again, this is due to low sample size of the Early Neolithic Iberia dataset.

\subsection{Testing population continuity with Neolithic north Syria}

To gain better understanding into the demographic history of north Mesopotamia, we further studied the relationships between PPNB north Syria individuals ( $n=10$, Fernandez et al. 2014) and other west Eurasian groups. Comparing PPNB north Syria with modern-day populations we found no significant differentiation with Cyprus, Azerbaijan, and Georgia $\left(F_{S T}<0.05, p>0.05\right)$, low but significant differentiation with Syria, Jordan, southeast Anatolia, and Sicily $\left(F_{S T}<0.05, p<0.05\right)$, and moderate differentiation with modern-day Greece, Iran, and Armenia $\left(0.05<F_{S T}<0.10, p<0.05\right)$ (Supplementary Table S5). We conducted simulations comparing Neolithic north Syria with modern-day Syria, southeast Anatolia, Iran, Greece, and Armenia: continuity was rejected in all comparisons $(>75 \%$ of parameter value combinations with $p<0.10)$ except for modern-day Syria (77\% of parameter value combinations with $p>0.10$ ) (Fig. 4B, SI Fig. 4D,E).

In addition, we found that Neolithic north Syria had low differentiation with Neolithic northwest Anatolia, Çemialo Sırtı, and Roman Anatolia $\left(F_{S T}<0.05\right.$, non-significant in permutations).

Simulations did not reject continuity in either of the three comparisons $(>99 \%$ of parameter value combinations with $p>0.10$ ). Most other comparisons between Neolithic north Syria and ancient populations had moderate to high $F_{S T}$ values $\left(F_{S T}>0.05\right.$; Supplementary Table S5).

\section{Discussion}


Material culture evidence suggests Çemialo Sırtı was a Late Achaemenid-related settlement, although earlier nomadic and later Hellenic influences are also observed. Radiocarbon data complies with this Late Achaemenid-later Hellenistic time window (535-205 cal. BCE, including all 3 dated individuals' $95 \%$ intervals). The mitochondrial haplotype composition of the Çemialo Surt1 sample, including macrohaplogroups $\mathrm{H}, \mathrm{HV}, \mathrm{M}, \mathrm{N}, \mathrm{R}$ and $\mathrm{U} 2$, is generally similar to both earlier and later regional populations (Table 1). Macrohaplogroup $\mathrm{H}$, comprising $>40 \%$ of the dataset, is still one of the most abundant types in west Eurasia (Achilli et al., 2004; Richards et al., 2000). Of note, we found one instance of macrohaplogroup $M$ - this type was previously suggested to have been introduced in the region from Central Asia by Seljuk invasions in the eleventh century CE (Ottoni et al., 2016), while our detection of M in Iron Age CML contradicts this claim. We also observe an individual with haplogroup U2, intriguing as U haplogroups belong to a lineage associated with Palaeolithic and Mesolithic individuals of Europe (Bramanti et al., 2009; Brandt et al., 2014; Der Sarkissian et al., 2013; Krause et al., 2010) Overall, Çemialo Sırtı was not only culturally diverse, but also diverse in its maternal lineages.

Although north Mesopotamia was under Persian (Achaemenid) and Hellen political and cultural influence in the late 1st millennium (section 1), Çemialo Sırtı mtDNA composition did not show exceptional affinity to either modern-day Iran, or to Greece. Instead, Çemialo Sırtı was closest to Neolithic north Syria and northwest Anatolia. Among modern-day populations, it was closest to Cyprus, Jordan, Azerbaijan, and then to SE Anatolia and Syria; a similar pattern was found for Neolithic north Syria (Fig. 3). These observations suggest that genetic differentiation that occurred in north Mesopotamian populations over the past ten millennia, from the Neolithic to the Iron Age, and to the present, was modest $\left(F_{S T}<0.05\right)$. Our simulations further show that regional population continuity cannot be rejected in most comparisons (SI Fig. 4), and migration need not necessarily be invoked. We could neither reject continuity in comparisons of Neolithic north Syria versus Çemialo Sırt1, nor in comparisons of Çemialo Sırtı versus modern-day Syria or southeast Anatolia (Fig. 4, SI Fig. 4A, B), implying uninterrupted continuity over ten millennia (although lack of significance is partly attributable to low sample sizes in the ancient datasets).

The notion of regional continuity appears at odds with another observation arising both from our analysis and from earlier work: throughout the Holocene, within-population genetic diversity rose in west Eurasia, possibly via admixture among genetically distinct populations (Günther and Jakobsson, 2016; K1lınç et al., 2016; Lazaridis et al., 2016; Skoglund et al., 2014). Remarkably, haplotype diversity in Late Iron Age Çemialo Sırtı was the highest among ancient populations and on a par with those of modern-day west Eurasian populations, while Neolithic north Syria had one of the lowest diversity estimates. This difference in diversity between diachronic populations from the same region implies admixture events did take place in between the Neolithic and Late Iron Age periods.

To reconcile these two observations, i.e. continuity and increasing diversity, we suggest that extensive population replacement [as what happened during European Neolithization (Skoglund et al., 2014)] did not take place in north Mesopotamia within the last 10,000 years. Shifts in north Mesopotamian maternal genetic composition by immigration from genetically distinct populations must have occurred only at modest scales, undetectable at our current resolution. Alternatively, if the region's population size was constantly large, any immigrant alleles would be rapidly diluted. Thus, despite the turbulent sociopolitics of north Mesopotamian history, the maternal lineage appears to have remained largely continuous, reminiscent of population continuity reported for the Levant (Haber et al., 2016) and for Armenia (Margaryan et al., 2017). Whether this description equally applies to nuclear genomic variation remains to be shown. 
bioRxiv preprint doi: https://doi.org/10.1101/172890; this version posted August 6,2017 . The copyright holder for this preprint (which was not certified by peer review) is the author/funder. All rights reserved. No reuse allowed without permission.

\section{Acknowledgements}

We thank the Batman Museum and Claudio Ottoni for support, all members of the METU ancient DNA, METU CompEvo and Çemialo Sırtı teams, especially Füsun Özer, Eren Yüncü, Nihan Dilşad Dağtaş and Aliye Gündüzalp for support and helpful discussions, Düzce University Archeology Department students for help, and Düzce University for the access to the DU Biological Anthropology Laboratory. This work was funded by the Scientific and Technological Research Council of Turkey (TÜBİTAK grant no. 114Z159) and METU (BAP-07-02-2015-003). 


\section{References}

Achilli, A., Rengo, C., Magri, C., Battaglia, V., Olivieri, A., Scozzari, R., ... Torroni, A. (2004). The molecular dissection of mtDNA haplogroup H confirms that the Franco-Cantabrian glacial refuge was a major source for the European gene pool. American Journal of Human Genetics, 75(5), 910-8. https://doi.org/10.1086/425590

Ahmad, M. H., Hamid, M., Koumleh, M. H., Roostapoor, N. (2013). The Comparison of the Materials in Styles of Iranian Architecture and its Effect on the Form of the Building before the Islam's Entry to Iran. IOSR Journal of Mechanical and Civil Engineering (IOSR-JMCE), $8(3), 50-54$.

Algaze, G., P. Goldberg, D. Honça, T. Matney, A. Misır, A. Rosen, D. Schlee and L. Somers (1995) Titriş Höyük, A Small EBA Urban Center in Southeastern Anatolia: the 1994 Season. Anatolica, 21, 13-64.

Alkan, C., Kavak, P., Somel, M., Gokcumen, O., Ugurlu, S., Saygi, C., ... Bekpen, C. (2014). Whole genome sequencing of Turkish genomes reveals functional private alleles and impact of genetic interactions with Europe, Asia and Africa. BMC Genomics, 15(1), 963. https://doi.org/10.1186/1471-2164-15-963

Anderson, S., Bankier, A. T., Barrell, B. G., de Bruijn, M. H., Coulson, A. R., Drouin, J., ... Young, I. G. (1981). Sequence and organization of the human mitochondrial genome. Nature, 290(5806), 457-465. https://doi.org/10.1038/290457a0

Balloux, F., Handley, L.-J. L., Jombart, T., Liu, H., and Manica, A. (2009). Climate shaped the worldwide distribution of human mitochondrial DNA sequence variation. Proceedings of the The Royal Society, Biological Sciences, 276(1672), 3447-55. https://doi.org/10.1098/rspb.2009.0752

Bramanti, B., Thomas, M. G., Haak, W., Unterlaender, M., Jores, P., Tambets, K., ... Burger, J. (2009). Genetic Discontinuity Between Local Hunter-Gatherers and Central Europe's First Farmers. Science, 326(5949), 137-140. https://doi.org/10.1126/science.1176869

Brandt, G., Haak, W., Adler, C. J., Roth, C., Szécsényi-, A., Karimnia, S., ... Consortium, T. G. (2014). Ancient DNA reveals key stages in the formation of Central European mitochondrial genetic diversity. Science, 342(6155), 257-261. https://doi.org/10.1126/science.1241844

Brisighelli, F., lvarez-Iglesias, V., Fondevila, M., Blanco-Verea, A., Carracedo, ??ngel, Pascali, V. L., ... Salas, A. (2012). Uniparental Markers of Contemporary Italian Population Reveals Details on Its Pre-Roman Heritage. PLoS ONE, 7(12). https://doi.org/10.1371/journal.pone.0050794

Büntgen, U., Myglan, V.S., Ljungqvist, F.C., McCormick, M., Di Cosmo, N., Sigl, $\quad$ M., ... Kirdyanov, A.V., (2016). Cooling and societal change during the Late Antique Little Ice Age from 536 to around 660 AD. Nature Geoscience 9, 231-236. https://doi.org/10.1038/ngeo2652

Comas, D., Calafell, F., Mateu, E., Perez-Lezaun, A., and Bertranpetit, J. (1996). Geographic variation in human mitochondrial DNA control region sequence: the population history of Turkey and its relationship to the European populations. Molecular Biology Evolution, 13(8), 1067-1077.

Comas, D., Plaza, S., Wells, R. S., Yuldaseva, N., Lao, O., Calafell, F., and Bertranpetit, J. (2004). Admixture, migrations, and dispersals in Central Asia: evidence from maternal DNA lineages. European Journal of Human Genetics : EJHG, 12(6), 495-504. https://doi.org/10.1038/sj.ejhg.5201160

Curtis, J. and Tallis, N. (2005). Forgotten Empire: The World of Ancient Persia. University of California Press. ISBN: 0-520- 24731-0.

Curtis, J. (2004). L'archéologie de l'empire achéménide. The Achaemenid Period in Northern Iraq. Colloque L'archéologie de l'empireachéménide Paris, Collège de France.

Der Sarkissian, C., Balanovsky, O., Brandt, G., Khartanovich, V., Buzhilova, A., Koshel, S., ... Haak, W. (2013). Ancient DNA Reveals Prehistoric Gene-Flow from Siberia in the Complex 
Human Population History of North East Europe. PLoS Genetics, 9(2).

https://doi.org/10.1371/journal.pgen.1003296

Excoffier, L., Dupanloup, I., Huerta-Sánchez, E., Sousa, V. C., and Foll, M. (2013). Robust

Demographic Inference from Genomic and SNP Data. PLoS Genetics, 9(10).

https://doi.org/10.1371/journal.pgen.1003905

Excoffier, L., and Lischer, H. E. L. (2010). Arlequin suite ver 3.5: A new series of programs to perform population genetics analyses under Linux and Windows. Molecular Ecology

Resources, 10(3), 564-567. https://doi.org/10.1111/j.1755-0998.2010.02847.x

Fernández, E., Pérez-Pérez, A., Gamba, C., Prats, E., Cuesta, P., Anfruns, J., ... Turbón, D. (2014). Ancient DNA Analysis of 8000 B.C. Near Eastern Farmers Supports an Early Neolithic Pioneer Maritime Colonization of Mainland Europe through Cyprus and the Aegean Islands. PLoS Genetics, 10(6). https://doi.org/10.1371/journal.pgen.1004401

Gamba, C., Fernández, E., Tirado, M., Deguilloux, M. F., Pemonge, M. H., Utrilla, P., ... Arroyo-Pardo, E. (2012). Ancient DNA from an Early Neolithic Iberian population supports a pioneer colonization by first farmers. Molecular Ecology, 21(1), 45-56.

https://doi.org/10.1111/j.1365-294X.2011.05361.x

Gilbert, M. T. P., Bandelt, H. J., Hofreiter, M., and Barnes, I. (2005). Assessing ancient DNA studies. Trends in Ecology and Evolution, 20(10), 541-544. https://doi.org/10.1016/j.tree.2005.07.005

González, A. M., Larruga, J. M., Abu-Amero, K. K., Shi, Y., Pestano, J., and Cabrera, V. M. (2007). Mitochondrial lineage M1 traces an early human backflow to Africa. BMC Genomics, 8, 223. https://doi.org/10.1186/1471-2164-8-223

Günther, T., Jakobsson, M. (2016) Genes mirror migrations and cultures in prehistoric Europe-a population genomic perspective. Current Opinion in Genetics and Development. 41:115-123. doi:10.1016/j.gde.2016.09.004

Haber, M., Mezzavilla, M., Xue, Y., and Tyler-Smith, C. (2016). Ancient DNA and the rewriting of human history: be sparing with Occam's razor. Genome Biology, 17(1), 1. https://doi.org/10.1186/s13059-015-0866-z

Hauptmann, H. (1982) Lidar Höyük, Anatolian Studies, 32: 17-18. $\square$

Hauptmann, H. (1984) Lidar Höyük, Anatolian Studies, 34:226 - 228.

Hauptmann, H. (1987) Lidar Höyük and Nevali Çori 1986, Anatolian Studies, 37: 203-206.

Hauptmann, H. (1993) Vier Jahrtausentend Siedlungsgeschichte am Mittleren Euphrat, Archäologie in Deutschland, 1(Jan-Mar. 1993):10-15.

Hughey, J. R., Paschou, P., Drineas, P., Mastropaolo, D., Lotakis, D. M., Navas, P. A., ... Stamatoyannopoulos, G. (2013). A European population in minoan Bronze age crete. Nature Communications, 30(4), 456-466. https://doi.org/10.1038/ncomms2871

Irwin, J., Saunier, J., Strouss, K., Paintner, C., Diegoli, T., Sturk, K., ... Parsons, T. J. (2008). Mitochondrial control region sequences from northern Greece and Greek Cypriots.

International Journal of Legal Medicine, 122(1), 87-89. https://doi.org/10.1007/s00414-007-0173-7

Jones, E. R., Gonzalez-Fortes, G., Connell, S., Siska, V., Eriksson, A., Martiniano, R., ... Walsh, S. (2015). Upper Palaeolithic genomes reveal deep roots of modern Eurasians. Nature Communications, 6, 8912. https://doi.org/10.1038/ncomms9912

Kılınç, G. M., Omrak, A., Özer, F., Günther, T., Büyükkarakaya, A. M., Bıçakçı, E., ... Götherström, A. (2016). The Demographic Development of the First Farmers in Anatolia. Current Biology, 26(19), 2659-2666. https://doi.org/10.1016/j.cub.2016.07.057

Krause, J., Briggs, A. W., Kircher, M., Maricic, T., Zwyns, N., Derevianko, A., and Pääbo, S. (2010). A Complete mtDNA Genome of an Early Modern Human from Kostenki, Russia. Current Biology, 20(3), 231-236. https://doi.org/10.1016/j.cub.2009.11.068

Kuzucuoğlu, C. (2015) The Rise and Fall of the Hittite State in Central Anatolia, How, When, Where, Did Climate Intervene?, in: Beyer D., Henry O., Tibet A. (Eds.), La Cappadoce 
Méridionale de la préhistoire à la période Byzantine. IFEA, 17-41.

Lacan, M., Keyser, C., Ricaut, F.-X., Brucato, N., Durathon, F., Guilaine, J., ... Ludes, B. (2011). Ancient DNA reveals male diffusion through the Neolithic Mediterranean route. PNAS, 108(24), 9788-9791. https://doi.org/10.1073/pnas.1100723108

Lazaridis, I. P., Nadel, D., Rollefson, G., Merrett, D. C., Rohland, N., Mallick, S., ... Reich, D. (2016). Genomic insights into the origin of farming in the ancient Near East. Nature, 536(7617), 419-424. https://doi.org/10.1038/nature19310

Lazaridis, I., Patterson, N., Mittnik, A., Renaud, G., Mallick, S., Kirsanow, K., ... Krause, J. (2014). Ancient human genomes suggest three ancestral populations for present-day Europeans. Nature, 513(7518), 409-13. https://doi.org/10.1038/nature13673

Margaryan, A., Derenko, M., Hovhannisyan, H., Malyarchuk, B., Heller, R., Khachatryan, Z., ... Allentoft, M. E. (2017). Eight Millennia of Matrilineal Genetic Continuity in the South Caucasus. Current Biology, 27(13), 2023-2028.e7. https://doi.org/10.1016/j.cub.2017.05.087

Marro, C. (2010). Where did Late Chalcolithic Chaff-Faced Ware originate? Cultural Dynamics in Anatolia and Transcaucasia at the Dawn of Urban Civilization (ca 4500-3500 BC). Paléorient, 36(2), 35-55.

Mathieson, I., Lazaridis, I., Rohland, N., Mallick, S., Patterson, N., Roodenberg, S. A., ... Reich, D. (2015). Genome-wide patterns of selection in 230 ancient Eurasians. Nature, 528(7583), 499-503. https://doi.org/10.1038/nature 16152

Matney, T., and Algaze G. (1995) Urban development at Mid-Late Early Bronze Age Titriş Höyük in Southeastern Anatolia, BASOR, 299/300: 33-52.

Nasidze, I., Stoneking, M. (2001). Mitochondrial DNA variation and language replacements in the Caucasus. Proceedings of the Royal Society Biological Sciences, 268(1472), 1197-206. https://doi.org/10.1098/rspb.2001.1610

Nei and Kumar. (2000). Molecular Evolution and Phylogenetics. Oxford University Press, Oxford.

Oksanen, J. (2008). Vegan: an introduction to ordination. Management, 1, 1-10. https://doi.org/intro-vegan.Rnw 1260 2010-08-17 12:11:04Z jarioksa processed with vegan 1.17-6 in R version 2.12.1 (2010-12-16) on January 10, 2011.

Nissen, H.J. and Heine P. (2009). From Mesopotamia to Iraq: a concise history. The University of Chicago Press, Chicago.

Oates, D. and Oates, J. (1958). Nimrud 1957: The Hellenistic Settlement. Iraq, 20, 114-57

Olivieri, C., Ermini, L., Rizzi, E., Corti, G., Bonnal, R., Luciani, S., ... Rollo, F. (2010). Characterization of nucleotide misincorporation patterns in the Iceman's mitochondrial DNA. PLoS ONE, 5(1). https://doi.org/10.1371/journal.pone.0008629

Ottoni, C., Rasteiro, R., Willet, R., Talloen, P., Vijver, K. Van De, Poblome, J., and Decorte, R. (2016). Comparing maternal genetic variation across two millennia reveals the demographic history of an ancient human population in southwest Turkey. Royal Society Open Science, 3, 150250. https://doi.org/10.1098/rsos.150250

Ottoni, C., Ricaut, F.-X., Vanderheyden, N., Brucato, N., Waelkens, M., and Decorte, R. (2011). Mitochondrial analysis of a Byzantine population reveals the differential impact of multiple historical events in South Anatolia. European Journal of Human Genetics, 19(5), 571-576. https://doi.org/10.1038/ejhg.2010.230

Paabo, S., Poinar, H., Serre, D., Jaenicke-Despres, V., Hebler, J., Rohland, N., ... Hofreiter, M. (2004). Genetic analyses from ancient DNA. Annual Review of Genetics, 38, 645-679. https://doi.org/10.1146/annurev.genet.37.110801.143214

Richards, M., Macaulay, V., Hickey, E., Vega, E., Sykes, B., Guida, V., ... Hans-Jürgen, B. (2000). Tracing european founder lineages in the near eastern mtDNA pool. American Journal of Human Genetics, 67(5), 1251-1276. https://doi.org/10.1016/S0002-9297(07)62954-1

Roostalu, U., Kutuev, I., Loogväli, E. L., Metspalu, E., Tambets, K., Reidla, M., ... Villems, R. (2007). Origin and expansion of haplogroup $\mathrm{H}$, the dominant human mitochondrial DNA lineage in west Eurasia: The Near Eastern and Caucasian perspective. Molecular Biology and 
Evolution, 24(2), 436-448. https://doi.org/10.1093/molbev/msl173

Sampson, Gareth C. (2008). The Defeat of Rome: Crassus, Carrhae and the Invasion of the East. Pen and Sword Books Limited. p. 33. ISBN 9781844156764.

Sawyer, S., Krause, J., Guschanski, K., Savolainen, V., and Paabo, S. (2012). Temporal patterns of nucleotide misincorporations and DNA fragmentation in ancient DNA. PLoS ONE, 7(3). https://doi.org/10.1371/journal.pone.0034131

Schechla, J. (1993). Ideological roots of population transfer. Third World Quarterly, 14(2), 239-275. https://doi.org/10.1080/01436599308420324

Schönberg, A., Theunert, C., Li, M., Stoneking, M., and Nasidze, I. (2011). High-throughput sequencing of complete human mtDNA genomes from the Caucasus and West Asia: high diversity and demographic inferences. European Journal of Human Genetics : EJHG, 19(9), 988-94. https://doi.org/10.1038/ejhg.2011.62

Serin, A., Canan, H., Alper, B., Korkut Gulmen, M., Zimmermann, B., and Parson, W. (2016). Mitochondrial DNA control region haplotype and haplogroup diversity in South Eastern Turkey. Forensic Science International: Genetics, 24, 176-179. https://doi.org/10.1016/j.fsigen.2016.07.011

Skoglund, P., Malmstrom, H., Omrak, A., Raghavan, M., Valdiosera, C., Gunther, T., ... Jakobsson, M. (2014). Genomic Diversity and Admixture Differs for Stone-Age Scandinavian Foragers and Farmers. Science, 344(6185), 747-750. https://doi.org/10.1126/science.1253448

Slatkin, M. (1995). A measure of population subdivision based on microsatellite allele frequencies. Genetics, 139(1), 457-462. https://doi.org/Article

Staubwasser, M. and Weiss, H. (2006). Holocene climate and cultural evolution in late prehistoric-early historic West Asia. Quaternary Research, 66(3), 372-387

Sverrisdóttir, O. Ó., Timpson, A., Toombs, J., Lecoeur, C., Froguel, P., Carretero, J. M., ... Thomas, M. G. (2014). Direct estimates of natural selection in iberia indicate calcium absorption was not the only driver of lactase persistence in Europe. Molecular Biology and Evolution, 31(4), 975-983. https://doi.org/10.1093/molbev/msu049

Szécsényi-Nagy, A., Brandt, G., Haak, W., Keerl, V., Möller-Rieker, S., Köhler, K., ... Alt, K. W. (2015). Tracing the genetic origin of Europe's first farmers reveals insights into their social organization. Proceedings of the Royal Society B, Biological Sciences, 282, 20150339. https://doi.org/10.1098/rspb.2015.0339

Thompson, J. D., Higgins, D. G., and Gibson, T. J. (1994). CLUSTAL W: Improving the sensitivity of progressive multiple sequence alignment through sequence weighting, position-specific gap penalties and weight matrix choice. Nucleic Acids Research, 22(22), 4673-4680. https://doi.org/10.1093/nar/22.22.4673

van Oven, M., Kayser M. (2009). Updated comprehensive phylogenetic tree of global human mitochondrial DNA variation. Human Mutation, 30(2), E386-E394. http://www.phylotree.org. doi:10.1002/humu.20921

Vernesi, C., Di Benedetto, G., Caramelli, D., Secchieri, E., Simoni, L., Katti, E., ... Barbujani, G. (2001). Genetic characterization of the body attributed to the evangelist Luke. PNAS, 98(23), 13460-13463. https://doi.org/10.1073/pnas.211540498

Weninger, B., Clare, L., Rohling, E. J., Bar-Yosef, O., Böhner, U., Budja, M., Bundschuh, M., Feurdean, A., Gebel, $\square$ H.G., Jöris, O., Linstädter, J., Mayewski, P., Mühlenbruch, T., $\square$ A. Reingruber, A., Rollefson, G., Schyle, D., Thissen, L., Todorova, H., Zielhofer, C. (2009). The Impact of Rapid Climate Change on prehistoric societies during the Holocene in the Eastern Mediterranean, Documenta Praehistorica, XXXVI, 7-59.

Weninger, B., Clare, L., Gerritsen, F. , Horejs, B., Krauß, R., Linstädter, J., Özbal, R. and Rohling, E. J. (2014). Neolithisation of the Aegean and Southeast Europe during the 6600-6000 cal BC period of Rapid Climate Change, Documenta Praehistorica, XLI, 1- 31.

Weninger B., Alram-Stern E., Bauer E., Clare L., Danzeglocke U., Jöris O., Kubatzki C., Rollefson G., Todorova H. and van Andel T. (2006). Climate forcing due to the $8200 \mathrm{cal}$ yr BP event 
observed at Early Neolithic sites in the eastern Mediterranean. Quaternary Research, 66, 401420 .

Woolf, G. (2016). Moving Peoples in the Early Roman Empire. In: The impact of mobility and migration in the Roman Empire. Impact of Empire (12). Brill, Leiden and Boston. (Unpublished)

Yağız, K. (2009) Antandros Nekropolisi Hellenistik Dönem Mezar Tipleri. Adlyaman Üniversitesi Sosyal Bilimler Enstitüsü Dergisi, 2, 136-144.

http://dergipark.ulakbim.gov.tr/adyusbd/article/view/5000041846/5000039374

Zürcher, E-J. (2009). The Late Ottoman Empire as Laboratory of Demographic Engineering. Il Mestiere Di Storico. 1:7-18. http://digital.casalini.it/10.1400/148038 


\section{Tables}

Table 1. Haplogroup frequencies (N) together with the 95\% Bayesian credible intervals (CI) estimated for Late Iron Age Çemialo Surt1, Neolithic north (N) Syria, and for modern-day southeast (SE) Anatolia and Syria population samples. Data sources are described in Table S3 .

\begin{tabular}{|c|c|c|c|c|c|c|c|c|}
\hline \multirow[b]{2}{*}{ Haplogroup } & \multicolumn{2}{|c|}{$\begin{array}{l}\text { Late Iron Age } \\
\text { Çemialo Sırtı }\end{array}$} & \multicolumn{2}{|c|}{$\begin{array}{l}\text { Neolithic } \\
\text { N Syria }\end{array}$} & \multicolumn{2}{|c|}{$\begin{array}{l}\text { Modern-day } \\
\text { SE Anatolia }\end{array}$} & \multicolumn{2}{|c|}{$\begin{array}{c}\text { Modern-day } \\
\text { Syria }\end{array}$} \\
\hline & $\%(N)$ & CI & $\%(N)$ & CI & $\%(N)$ & CI & $\%(N)$ & CI \\
\hline $\mathbf{A}$ & 0 & $0-25$ & 0 & $0-28$ & $0.9(2)$ & $0-3$ & 0 & $0-7$ \\
\hline B & 0 & $0-25$ & 0 & $0-28$ & $1.3(3)$ & $0-4$ & $2.1(1)$ & $0-11$ \\
\hline C & 0 & $0-25$ & 0 & $0-28$ & $3.6(8)$ & $2-7$ & 0 & $0-7$ \\
\hline D & 0 & $0-25$ & 0 & $0-28$ & $0.9(2)$ & $0-3$ & 0 & $0-7$ \\
\hline G & 0 & $0-25$ & 0 & $0-28$ & $0.9(2)$ & $0-3$ & 0 & $0-7$ \\
\hline H & $41.7(5)$ & $19-68$ & $10(1)$ & $2-41$ & $21(47)$ & $16-27$ & $18.8(9)$ & $10-32$ \\
\hline HV & $16.7(2)$ & $5-45$ & $20(2)$ & $6-52$ & $4.5(10)$ & $2-8$ & $8.3(4)$ & $3-20$ \\
\hline $\mathbf{I}$ & 0 & $0-25$ & 0 & $0-28$ & $1.8(4)$ & $1-4$ & 0 & $0-7$ \\
\hline $\mathbf{J}$ & 0 & $0-25$ & 0 & $0-28$ & $6.7(15)$ & $4-11$ & $6.3(3)$ & $2-17$ \\
\hline $\mathbf{K}$ & 0 & $0-25$ & $40(4)$ & $17-69$ & $5.8(13)$ & $3-10$ & $8.3(4)$ & $3-20$ \\
\hline LO & 0 & $0-25$ & 0 & $0-28$ & 0 & $0-2$ & 0 & $0-7$ \\
\hline $\mathbf{L}$ & 0 & $0-25$ & $10(1)$ & $2-41$ & $0.9(2)$ & $0-3$ & 0 & $0-7$ \\
\hline $\mathbf{M}$ & $8.3(1)$ & $2-36$ & 0 & $0-28$ & $0.4(1)$ & $0-2$ & 0 & $0-7$ \\
\hline N1 & $8.3(1)$ & $2-36$ & 0 & $0-28$ & $3.6(8)$ & $2-7$ & $2.1(1)$ & $0-11$ \\
\hline $\mathbf{N}^{*}$ & 0 & $0-25$ & $10(1)$ & $2-41$ & $0.4(1)$ & $0-2$ & 0 & $0-7$ \\
\hline Ro & 0 & $0-25$ & $10(1)$ & $2-41$ & $8.9(20)$ & $6-13$ & $2.1(1)$ & $0-11$ \\
\hline $\mathbf{R}$ & $16.7(2)$ & $5-45$ & 0 & $0-28$ & $2.2(5)$ & $1-5$ & $6.3(3)$ & $2-17$ \\
\hline $\mathbf{T}$ & 0 & $0-25$ & 0 & $0-28$ & $10.3(23)$ & $7-15$ & $12.5(6)$ & $6-25$ \\
\hline
\end{tabular}


bioRxiv preprint doi: https://doi.org/10.1101/172890; this version posted August 6,2017 . The copyright holder for this preprint (which was not certified by peer review) is the author/funder. All rights reserved. No reuse allowed without permission.

$\begin{array}{ccccccccr}\mathbf{U 1} & 0 & 0-25 & 0 & 0-28 & 1.3(3) & 0-4 & 2.1(1) & 0-11 \\ \mathbf{U 2} & 8.3(1) & 2-36 & 0 & 0-28 & 3.6(8) & 2-7 & 2.1(1) & 0-11 \\ \mathbf{U 3} & 0 & 0-25 & 0 & 0-28 & 7.6(17) & 5-12 & 12.5(6) & 6-25 \\ \mathbf{U 5} & 0 & 0-25 & 0 & 0-28 & 2.7(6) & 1-6 & 4.2(2) & 1-14 \\ \mathbf{U 7} & 0 & 0-25 & 0 & 0-28 & 4(9) & 2-7 & 2.1(1) & 0-11 \\ \mathbf{U} & 0 & 0-25 & 0 & 0-28 & 0 & 0-2 & 6.3(3) & 2-17 \\ \mathbf{W} & 0 & 0-25 & 0 & 0-28 & 5.4(12) & 3-9 & 2.1(1) & 0-11 \\ \mathbf{X} & 0 & 0-25 & 0 & 0-28 & 1.3(3) & 0-4 & 2.1(1) & 0-11\end{array}$




\section{Figures}

A

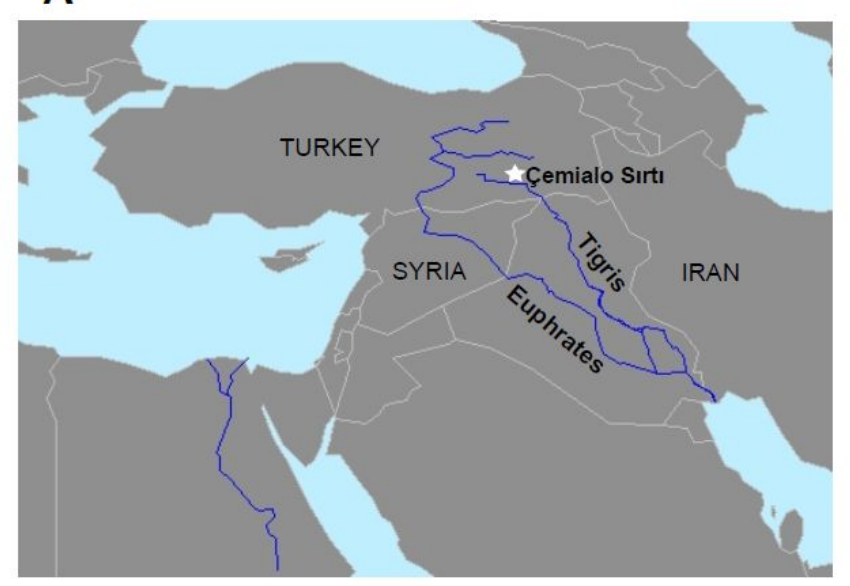

B

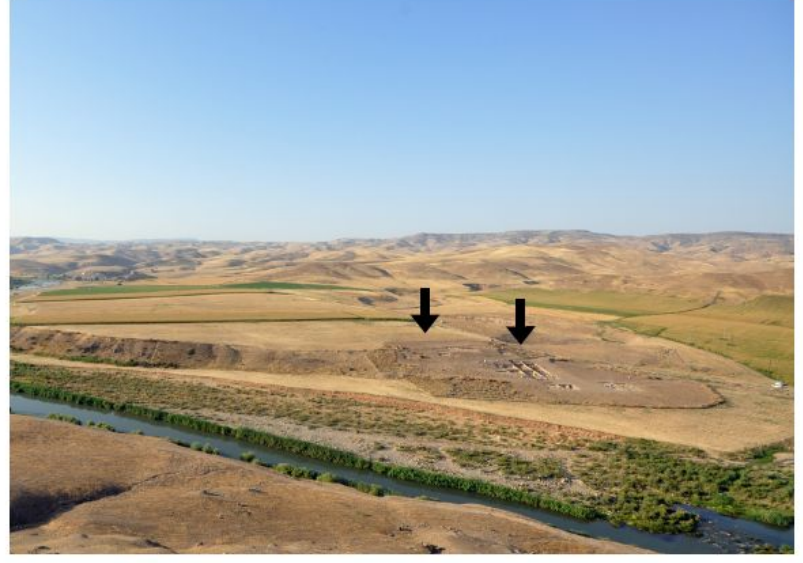

Fig. 1. The geographic location (A) and aerial view (B) of Çemialo Sırtı, Batman. Black arrows show the different regions of the excavation site. 


\section{A}

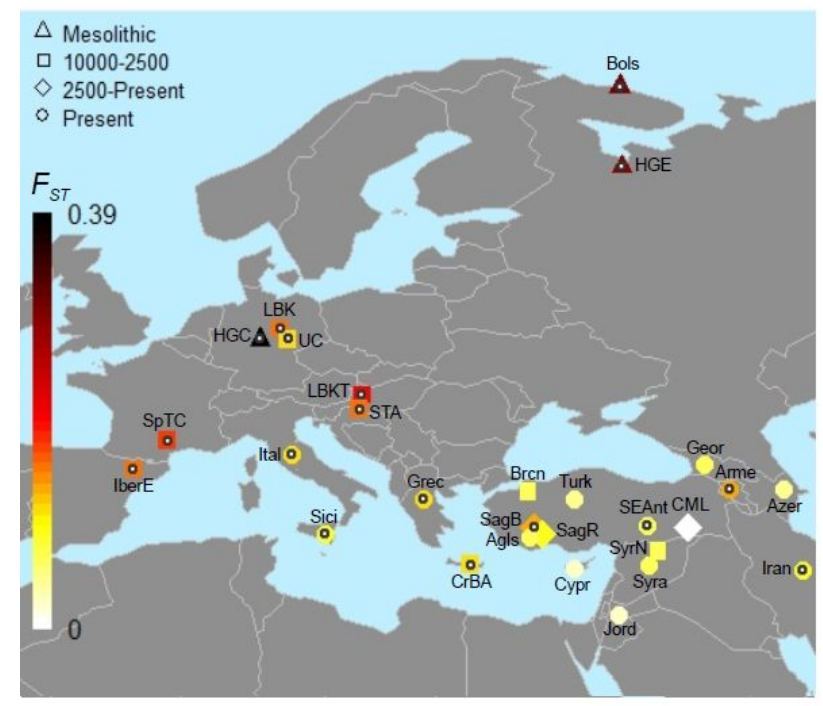

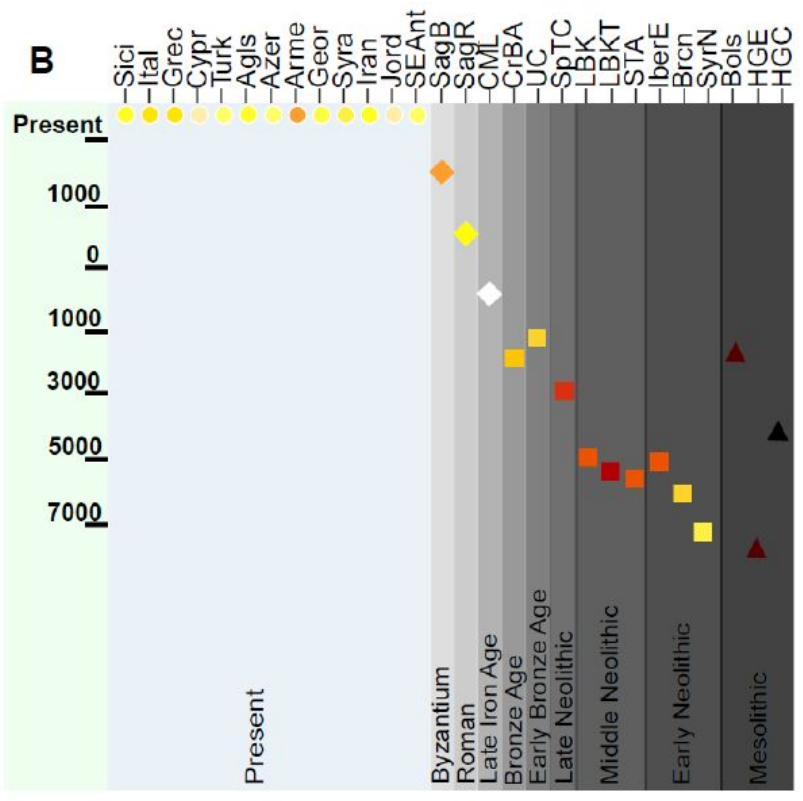

Fig. 2. Mitochondrial DNA differentiation $\left(F_{S T}\right)$ between the Çemialo Sırtı population and ancient or modern-day populations from west Eurasia. (A) The map shows the locations of the 15 ancient and 13 modern-day populations from west Eurasia. Shapes indicate the age or archaeological context of the population, the colors indicate level of $F_{S T}$ with Çemialo Sirtı according to the key on the left. Empty black circles indicate significant differentiation, as measured by random permutations $(\mathrm{p}<0.05)$. (B) The approximate ages of the populations included in the study (y-axis), with colors indicating $F_{S T}$ with Çemialo Sırtı (see Table S3 for more detail on the populations). Modern-day populations; Agls: southwest Anatolia (Aglasun), Arme: Armenia, Azer: Azerbaijan, Ital: Italy, Grec: Greece, Cypr: Cyprus, Geor: Georgia, Iran: Iran, Jord: Jordan, SEAnt: southeast Anatolia, Sici: Sicily, Syra: Syria, Turk: Turkey. Ancient populations; Bols: Bolshoy (Mesolithic northwest Russia), Bren: Barcın Höyük (Neolithic northwest Anatolia), CML: Çemialo Sırtı, CrBA: Crete Bronze Age (Minoan), HGC: Hunter-Gatherer of central Europe (Mesolithic central Europe), HGE: Hunter-Gatherer of east Europe (Mesolithic northwest Russia), IberE: Iberia Early Neolithic (Northeast Iberia), LBK: Linear Pottery culture (Neolithic central Europe), LBKT: Linearbandkeramik culture in Transdanubia (Neolithic central Europe), SagB: Sagalassos Byzantium (Southwest Anatolia), SagR: Sagalassos Roman (Southwest Anatolia), SpTC: Spain Treilles culture (Late Neolithic west Europe), STA: Early Neolithic Starčevo culture (Neolithic central Europe), SyrN: Neolithic north Syria, UC: Unetice culture (Early Bronze Age central Europe). 
A

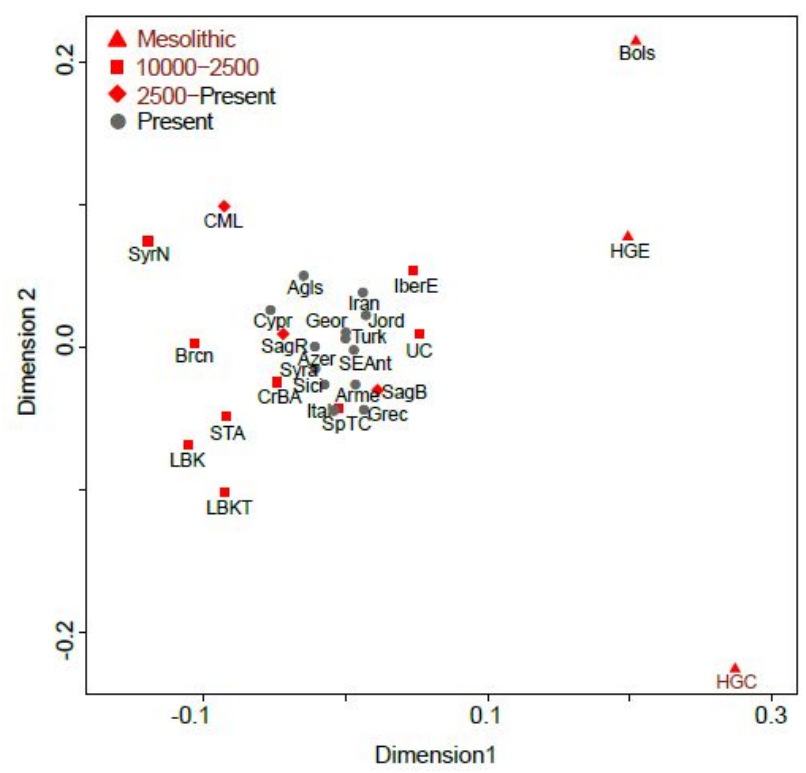

B

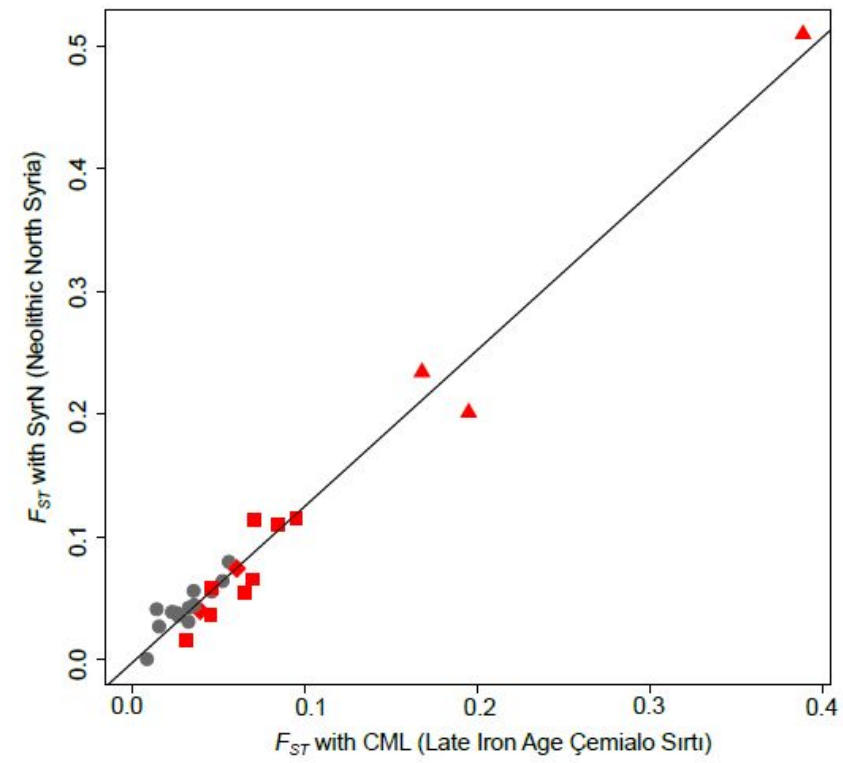

Fig. 3. Mitochondrial DNA differentiation across ancient and modern-day populations. (A) Multidimensional scaling (MDS) plot summarizing mtDNA $F_{S T}$ measures across 15 ancient and 13 modern-day populations from west Eurasia (Table S3). The abbreviations follow Fig. 2. The MDS calculation had a stress value of 0.13. (B) $F_{S T}$ between Çemialo Sırtı (x-axis) or the north Syrian Neolithic (y-axis) with third populations. 
A

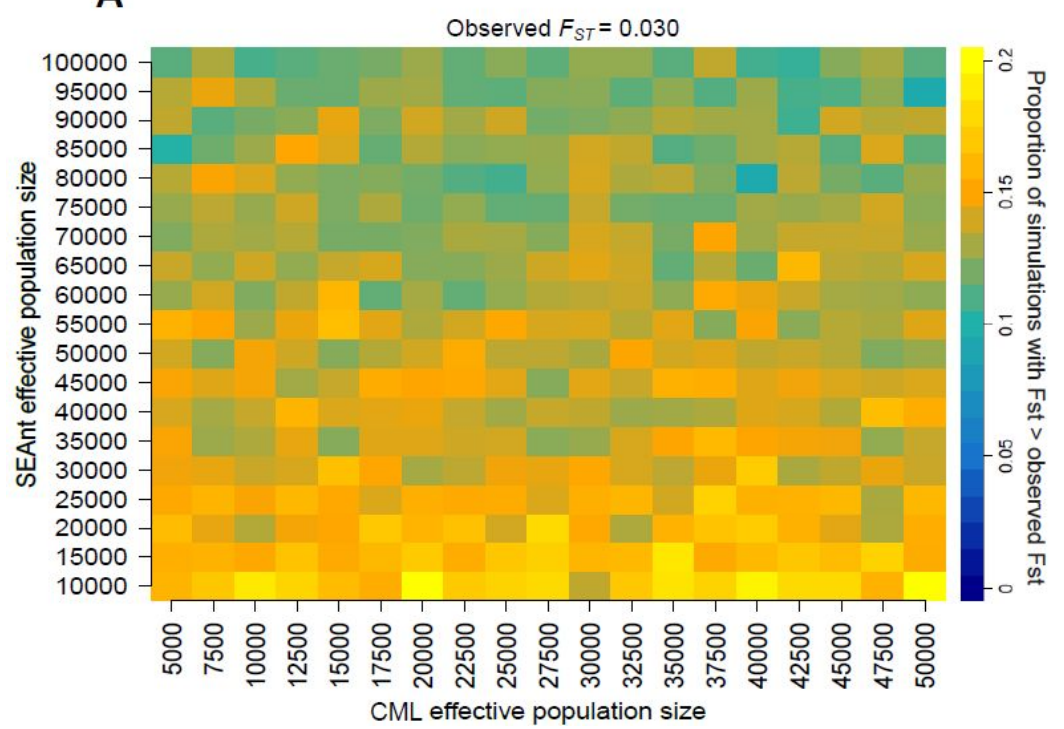

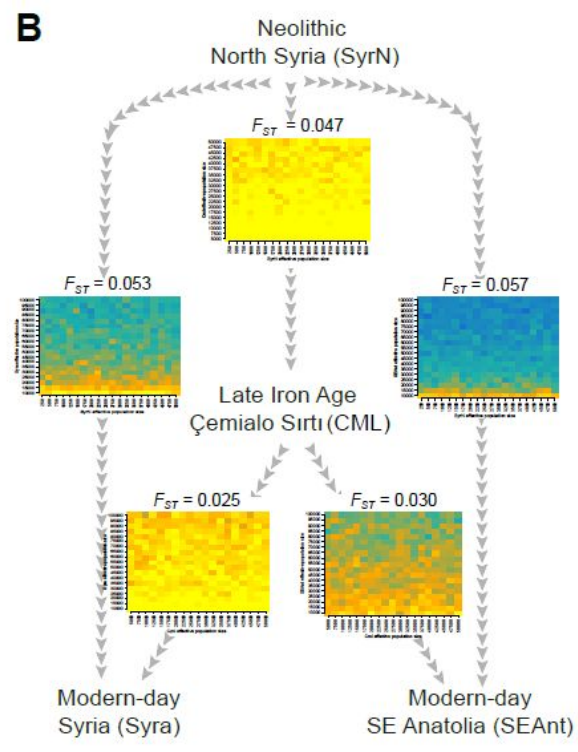

Fig. 4. Regional population continuity tested by simulation. (A) The grid represents the results of 19 X 19 X 1000 serial coalescent simulations under an exponential growth model, starting with Late Iron Age Çemialo Sırtı (CML) and ending with modern-day southeast Anatolia (SEAnt). The effective population sizes of CML and SEAnt used in the simulations are shown on the $\mathrm{x}$ - and y-axes. The parameter ranges were chosen following (Sverrisdottir et al. 2014). The colors indicate the proportion of 1000 simulations in each grid that had $F_{S T}$ values greater than that observed $\left(F_{S T}=0.030\right)$, with warm colors indicating that the observed $F_{S T}$ can arise solely by genetic drift. The colder colors indicate that the observed $F_{S T}$ is less likely to have arisen by genetic drift, implying migration. (B) Results from 5 comparisons involving Neolithic north Syria, Later Iron Age Çemialo Sirt1, and modern-day Syria and SE Anatolia. 